\title{
Pola Pertumbuhan Lactobacillus sp. F213 Selama Fermentasi Pada Sari Buah Terung Belanda (Solanum betaceum Cav.)
}

\section{Growth Pattern of Lactobacillus sp. F213 During Fermentation in Tamarillo Juice (Solanum betaceum Cav.)}

\author{
Puspasecca Wya Saraswati $^{1}$, Komang Ayu Nocianitri ${ }^{1 *}$, Ni Made Indri Hapsari Arihantana ${ }^{1}$ \\ Program Studi Teknologi Pangan, Fakultas Teknologi Pertanian, Universitas Udayana \\ Kampus Bukit Jimbaran, Badung-Bali \\ *Penulis korespondensi: Komang Ayu Nocianitri, Email: nocianitri@unud.ac.id
}

\begin{abstract}
The objective of this research was to determine the growth pattern of Lactobacillus sp. F213 during fermentation in tamarillo juice (Solanum betaceum Cav.) and to obtain the fermentation time that showed optimal growth. This research used a Completely Randomized Design with fermentation time ( 0 hours, 4 hours, 8 hours, 12 hours, 16 hours, 20 hours, 24 hours, 28 hours and 32 hours) as a treatment. Each treatment was repeated 2 times to obtain 18 experimental units. Variable observed were total $\mathrm{LAB}$, total sugar, total acid and $\mathrm{pH}$. The data results were analysed with quantitative descriptive methods The results of this study indicated that the growth pattern of Lactobacillus sp. F213 in tamarillo juice during fermentation in 0-4 hours was in the lag phase, fermentation time of 8-12 hours was in an exponential growth phase or log phase, fermentation time of 16-20 hours was in the stationary phase and at the fermentation time of 24-32 hours was in the death phase. The optimal growth was obtained at 20 hours of fermentation time with a total value of LAB 9,08 Log CFU/ml.
\end{abstract}

Keywords: Lactobacillus sp. F213, fermentation time, growth pattern, tamarillo juice, probiotic drink

\section{PENDAHULUAN}

Probiotik adalah salah satu komponen yang tergolong ke dalam pangan fungsional dan didefiniskan sebagai mikroorganisme hidup yang mampu memberikan efek menguntungkan jika berada dalam usus dengan jumlah $10^{6} \mathrm{cfu} / \mathrm{ml}$ (BPOM 2005; FAO/WHO 2001). Lactobacillus sp. F213 merupakan bakteri asam laktat yang diisolasi dari feses bayi sehat yang memiliki potensi sebagai probiotik, karena bakteri ini mampu melewati simulasi kondisi saluran pencernaan, serta mampu melakukan agregasi, berkolonisasi di usus dan berinteraksi melawan Escherichia coli patogen (Sujaya, 2010).

Bakteri Asam Laktat sebagai mikroba probiotik membutuhkan suatu bahan sebagai pembawa (carrier) untuk sampai dalam saluran pencernaan (Reid et al., 2017), saat ini selain produk susu dan olahannya, minuman sari buah juga dapat digunakan sebagai media alternatif karena memiliki gula yang tinggi yang dapat dimanfaatkan untuk perkembangan bakteri probiotik (Ding dan Shah, 2008), selain itu sari buah juga merupakan produk minuman yang memiliki kandungan vitamin, mineral, serta antioksidan yang cukup tinggi sehingga baik bagi kesehatan tubuh (Prado et al., 2007). Beberapa penelitian terkait sari buah yang dijadikan pembawa dari bakteri probiotik yaitu seperti sari buah tomat (Yoon et al., 2004), sari buah murbei (Zubaidah et al., 2008), sari buah terung belanda, 
sari buah sirsak, sari buah jeruk bali dan sari buah jeruk siam (Rini et al., 2019)

Terung belanda merupakan salah satu jenis buah termasuk dalam family Solanaceae yang dapat dimanfaatkan sebagai bahan dasar minuman probiotik. Buah terung belanda memiliki rasa seperti tomat dengan kandungan gizi diantaranya yaitu, vitamin A, B, C, E, serat, protein, kalsium, fosfor, phytochemical termasuk $\beta$-karoten, antosianin, flavonol, asam fenolik, dan asam askorbat (Djufry et al., 2016).

Berdasarkan pernyataan Rini et al., (2019), sari buah terung belanda merupakan media yang paling cocok untuk pertumbuhan Lactobacillus sp. F213 dibandingkan dengan sari buah sirsak, sari buah jeruk bali maupun sari buah jeruk siam, karena total bakteri Lactobacillus sp, F213 yang dihasilkan sari buah terung belanda tanpa fermentasi yang disimpan selama 12 hari dengan suhu $4^{\circ} \mathrm{C}$ memiliki jumlah yang stabil sebanyak $10^{6}$ $\mathrm{cfu} / \mathrm{ml}$. Potensi ini selanjutnya dikembangkan dimana sari buah terung belanda kemudian difermentasi agar viabilitas dari Lactobacillus sp. F213 memenuhi syarat untuk dianggap sebagai minuman probiotik, yaitu berjumlah minimal sebanyak $10^{7} \mathrm{CFU} / \mathrm{ml}$.

Fermentasi merupakan suatu proses perubahan kimia pada suatu substrat organik melalui aktivitas enzim yang dihasilkan oleh mikroorganisme (Suprihatin, 2010). Keberhasilan dari fermentasi, tentunya berkaitan dengan faktorfaktor yang mempengaruhi kinetika pertumbuhan dari mikroba, adapun faktor-faktor tersebut yaitu suhu, $\mathrm{pH}$, tingkat oksigen terlarut, kecepatan agitasi, serta substrat yang sesuai (Wenge dan
Methews, 1999). Kinetika pertumbuhan dari mikroba, dapat digunakan untuk mengetahui gambaran dari faktor - faktor lingkungan yang optimal selama fermentasi sehingga fermentasi dapat dikendalikan untuk menghasilkan produk yang baik, adapun yang termasuk ke dalam kinetika pertumbuhan mikroba adalah pola pertumbuhan mikroba, periode waktu yang dibutuhkan untuk tumbuh dan beradaptasi, serta jumlah dari metabolit yang dihasilkan oleh mikroba (Yuliana, 2008). Terdapat empat fase utama selama pertumbuhan bakteri yaitu fase lag (fase lamban), fase ekponensial (fase pertumbuhan cepat), fase stasioner dan fase penurunan populasi (fase kematian).

Febricia et al. (2020) menyatakan bahwa bakteri Lactobacillus sp. F213 yang diinokulasikan pada sari buah terung belanda dengan lama fermentasi 22 sampai dengan 26 jam telah memasuki fase stasioner dengan jumlah total BAL yang dihasilkan yaitu 9,44 Log CFU/ml, selanjutnya dikemukakan bahwa waktu fermentasi terlama yang dilakuka yaitu fermentasi 26 jam, sehingga menyebabkan titik akhir fase stasioner dari bakteri Lactobacillus sp. F213 pada sari buah terung belanda yang telah difermentasi masih belum diketahui. Berdasarkan hal tersebut, maka diperlukan penelitian untuk mengamati bagaimana pola pertumbuhan dari Lactobacillus sp. F213 selama fermentasi pada sari buah terung belanda sehingga dapat menentukan bagaimana pola pertumbuhan dari Lactobacillus sp. F213 selama fermentasi dan berapa waktu fermentasi yang menghasilkan pertumbuhan bakteri yang optimal. 


\section{METODE PENELITIAN}

\section{Tempat dan Waktu}

Penelitian ini dilaksanakan di UPT. Laboratorium Terpadu Biosains dan Bioteknologi Universitas Udayana, Jl. Raya Kampus Udayana, Bukit Jimbaran. Penelitian ini dilaksanakan dari bulan Juli sampai September 2020.

\section{Bahan dan Alat}

Bahan yang digunakan dalam penelitian ini adalah isolat Lactobacillus sp. F213 (koleksi UPT Laboraturium Terpadu Biosains dan Bioteknologi Universitas Udayana), buah terung belanda yang diperoleh di daerah Kintamani dengan karakteristik dari daging buahnya berwarna kuning kemerahan, air mineral (Aqua), sukrosa, alkohol 96\%, de Man Rogosa Sharpe Agar (MRSA), de Man Rogosa Sharpe Broth (MRSB), akuades, $\mathrm{NaCl}$ 0,85\%, gliserol, kristal violet, larutan lugol, pewarna safranin, pereaksi Anthrone (Merck), $\mathrm{H}_{2} \mathrm{SO}_{4}$ pekat, phenolphtalein $1 \%$, glukosa standar, larutan buffer $\mathrm{pH} \mathrm{4,} 7$ dan 10, larutan $\mathrm{H}_{2} \mathrm{O}_{2}$, indikator $\mathrm{PP}, \mathrm{NaOH} 0,1 \mathrm{~N}, \mathrm{NaOH} 50 \%, \mathrm{HCl}$ $4 \mathrm{~N}$, alumunium foil dan tisu

Alat yang digunakan adalah botol kaca, gelas, baskom, cawan petri (Petriq), tabung reaksi (pyrex), jarum ose, inkubator, laminar air flow, spektrofotometer (evolution 201), pH-meter (martini instruments), timbangan analitik (Shimadzu AUX220), mikroskop (Olympus CX21FS1), pipet mikro (Finnpippete), pipet volume, labu ukur, erlenmeyer (pyrex), kertas saring, autoklaf, magnetic stirrer, waterbath (nvc thermologic), bunsen, blender, tip $100 \mu \mathrm{L}$, tip $1000 \mu \mathrm{L}$, vortex, gelas objek, freezer, pisau, talenan, kain saring, microtube (eppendorf), sentrifugasi (Clements GS150 centrifuge), gelas ukur, batang bengkok, kulkas, dan labu ukur.

\section{Rancangan Penelitian dan Analisa Data}

Penelitian ini menggunakan Rancangan Acak Lengkap (RAL) dengan perlakuan lama fermentasi yang terdiri dari 9 taraf sebagai berikut: $\mathrm{L}_{0}=$ Fermentasi selama 0 jam, $\mathrm{L}_{4}=$ Fermentasi selama 4 jam, $\mathrm{L}_{8}=$ Fermentasi selama 8 jam, $\mathrm{L}_{12}=$ Fermentasi selama 12 jam, $\mathrm{L}_{16}=$ Fermentasi selama 16 jam, $\mathrm{L}_{20}=$ Fermentasi selama 20 jam, $\mathrm{L}_{24}$ $=$ Fermentasi selama 24 jam, $\mathrm{L}_{28}=$ Fermentasi selama 28 jam, $\mathrm{L}_{32}=$ Fermentasi selama 32 jam.

Masing-masing perlakuan diulang sebanyak 2 kali sehingga diperoleh 18 unit percobaan. Data yang diperoleh dari hasil pengamatan akan dianalisis secara deskriptif kuantitatif. Metode analisis deskriptif kuantitatif adalah analisis untuk memberikan gambaran tentang data penelitian yang disajikan dalam bentuk tabel dan gambar, kemudian dijelaskan secara deskriptif.

\section{Pelaksanaan Penelitian}

\section{Penyegaran dan Konfirmasi Isolat}

Bakteri Lactobacillus sp F213 dilakukan penyegaran dengan cara diambil $100 \mu \mathrm{L}$ stok isolat yang disimpan dalam gliserol 30\% pada suhu $80^{\circ} \mathrm{C}$ dan diinokulasi pada $5 \mathrm{ml}$ media MRS Broth dan diikubasi selama 24 jam dengan suhu $37^{\circ} \mathrm{C}$. Hasil positif ditunjukkan dengan munculnya kekeruhan pada media. Setelah penyegaran, dilakukan konfirmasi isolat dengan uji katalase, pewarnaan gram dan uji gas. Uji katalase dilakukan untuk mengetahui apakah bakteri tersebut menghasilkan enzim katalase, adapun pengujian ini dilakukan dengan cara dibuat tetesan isolat pada 
gelas objek, kemudian ditetesi dengan dua tetes larutan $\mathrm{H}_{2} \mathrm{O}_{2}$, dan diamati gelembung yang timbul. Hasil positif ditunjukkan oleh timbulnya gelembung udara $\left(\mathrm{O}_{2}\right)$ yang dihasilkan dari degradasi $\mathrm{H}_{2} \mathrm{O}_{2}$ oleh enzim-enzim katalase (Suryani et al., 2010).

Pewarnaan gram dilakukan untuk mengetahui apakah bakteri tersebut termasuk ke dalam bakteri gram positif atau bakteri gram negatif, pengujian ini dilakukan dengan cara meneteskan isolat pada gelas objek kemudian difiksasi di atas bunsen dan diwarnai dengan kristal violet selama 1 menit, kemudian ditetesi dengan larutan lugol selama 1 menit. Selanjutnya gelas objek ditetesi aseton alkohol selama 1 menit dan terakhir diwarnai dengan pewarna safranin selama 5 detik. Sel bakteri yang telah diwarnai, dikeringkan dan diamati dibawah mikroskop (Suryani et al., 2010). Selanjutnya uji yang dilakukan adalah uji gas untuk mengetahui apakah bakteri tersebut termasuk ke dalam bakteri homofermentatif atau heterofermentatif. Uji gas dilakukan dengan metode hot loop, dengan cara memasukkan jarum ose panas ke dalam suspensi biakan BAL. Hasil positif ditandai oleh terbentuknya gas $\mathrm{CO} 2$ dan terbentuknya gelembung seperti buih dari hasil metabolisme glukosa (Suryani et al., 2010).

\section{Pembuatan Sari Buah Terung Belanda}

Buah terung belanda yang sudah disortasi, dicuci dengan bersih kemudian dipotong menjadi dua bagian, selanjutnya bagian daging buah dipisahkan dari kulitnya dan ditambahkan air dengan perbandingan 1:3. Daging buah yang sudah ditambahkan air selanjutnya dihancurkan dengan menggunakan juice extractor, kemudian disaring untuk menghasilkan sari buah tanpa ampas. Diagram alir pembuatan sari buah terung belanda dapat dilihat pada Gambar 1 .

\section{Pembuatan Starter}

Persiapan pembuatan starter diawali dengan pembuatan sari buah terung belanda yang akan digunakan sebagai substrat, dimana sari buah terung belanda diambil sebanyak $150 \mathrm{ml}$, kemudian ditambahkan dengan sukrosa sebanyak 5\% dan dipasteurisasi selama 4,5 menit pada suhu $80^{\circ} \mathrm{C}$. Setelah proses pasteurisasi selesai, sari buah didinginkan sampai mencapai suhu $37^{\circ} \mathrm{C}$. Selanjutnya diambil sebanyak $100 \mu \mathrm{L}$ Lactobacillus sp. F213 dari stok kultur dalam gliserol, kemudian dimasukkan ke dalam $5 \mathrm{ml}$ media MRSB dan selanjutnya diinkubasi selama 24 jam pada suhu $37^{\circ} \mathrm{C}$. Setelah inkubasi selesai, media diamati, jika terdapat kekeruhan pada media (menunjukkan hasil positif), maka tabung reaksi selanjutnya dihomogenkan lalu diambil sebanyak 1,5ml untuk dipindahkan ke dalam microtube, kemudian disentrifugasi dengan kecepatan 5000rpm selama 10 menit. Terbentuk endapan kultur mikroba pada dasar microtube. Supernatan di atas endapan kultur tersebut kemudian dibuang, sedangkan sel yang tertinggal dicuci sebanyak 3 kali. Pencucian sel dilakukan dengan cara menambahkan larutan saline sebanyak $1,5 \mathrm{ml}$ ke dalam microtube berisi endapan kultur, selanjutnya dihomogenkan dan disentrifugasi selama 10 menit dengan kecepatan 5000rpm. Larutan saline sisa dari pencucian terakhir dibuang, kemudian diambil sebanyak 1,5 ml dari $150 \mathrm{ml}$ substrat sari buah terung belanda dan dimasukkan ke dalam 
microtube. Microtube tersebut dihomogenkan dan kultur dalam microtube dimasukkan kembali dalam sari buah hingga yang sudah tersedia kemudian dikocok. Substrat sari buah tersebut kemudian difermentasi selama 24 jam pada suhu $37^{\circ} \mathrm{C}$. Diagram alir pembuatan starter dapat dilihat pada Gambar 2.

\section{Pembuatan Sari Buah Terung Belanda Terfermentasi}

Sari buah terung belanda yang sudah ditambahkan gula sebanyak $9 \%$ dimasukkan sebanyak $90 \mathrm{ml}$ ke dalam jar. Setelah itu, sari buah dipasteurisasi dengan suhu $80^{\circ} \mathrm{C}$ selama 4,5 menit dengan menggunakan waterbath dimana proses ini bertujuan untuk menghentikan aktivitas mikroba maupun enzimatik pada sari buah. Selanjutnya sari buah didinginkan hingga suhu mencapai $37^{\circ} \mathrm{C}$. Starter akan dimasukkan ke dalam jar yang berisi sari buah terung belanda sebanyak $10 \%$ pada masing-masing perlakuan, kemudian dikocok.
Setelah itu, sari buah terung belanda difermentasi pada suhu $37^{\circ} \mathrm{C}$ sesuai perlakuan $\mathrm{L}_{0}=0$ jam, $\mathrm{L}_{4}=4$ jam, $\mathrm{L}_{8}=8$ jam, $\mathrm{L}_{12}=12$ jam, $\mathrm{L}_{16}=16$ jam, $\mathrm{L}_{20}=20$ jam, $\mathrm{L}_{24}=24$ jam, $\mathrm{L}_{28}=28$ jam dan $\mathrm{L}_{32}=32$ jam. Diagram alir pembuatan sari buah terung belanda terfermentasi dapat dilihat pada Gambar 3.

\section{Variabel yang diamati}

Variabel yang diamati dalam penelitian ini adalah total BAL (Fardiaz, 1993), total gula dengan metode Anthrone (Andarwulan et al., 2011), total asam dengan metode titrasi netralisasi (Ruck, 1963) dan pH (Bouton dan Hariss, 1972).

\section{HASIL DAN PEMBAHASAN}

Hasil analisis pada pengaruh lama fermentasi terhadap total bakteri asam laktat (BAL), total gula, total asam dan $\mathrm{pH}$ dapat dilihat pada Tabel 1.

Tabel 1. Nilai rata-rata total BAL, total gula, total asam dan $\mathrm{pH}$ minuman probiotik sari buah terung belanda.

\begin{tabular}{ccccc}
\hline Lama Fermentasi $(\mathrm{jam})$ & Total BAL $(\mathrm{CFU} / \mathrm{ml})$ & Total Gula $(\%)$ & Total Asam $(\%)$ & $\mathrm{pH}$ \\
\hline 0 jam $\left(\mathrm{L}_{0}\right)$ & $8,15 \times 10^{6}$ & 20,38 & 0,4168 & 4.18 \\
4 jam $\left(\mathrm{L}_{4}\right)$ & $1,02 \times 10^{7}$ & 20,31 & 0,3685 & 4.27 \\
8 jam $\left(\mathrm{L}_{8}\right)$ & $2,2 \times 10^{7}$ & 19,51 & 0,3523 & 4.34 \\
12 jam $\left(\mathrm{L}_{12}\right)$ & $9,36 \times 10^{7}$ & 16,75 & 0,3270 & 4.40 \\
16 jam $\left(\mathrm{L}_{16}\right)$ & $8,48 \times 10^{8}$ & 16,66 & 0,3186 & 4.40 \\
20 jam $\left(\mathrm{L}_{20}\right)$ & $1,2 \times 10^{9}$ & 16,40 & 0,3163 & 4.41 \\
24 jam $\left(\mathrm{L}_{24}\right)$ & $7,99 \times 10^{8}$ & 16,25 & 0,3091 & 4.41 \\
28 jam $\left(\mathrm{L}_{28}\right)$ & $5,94 \times 10^{8}$ & 16,09 & 0,3027 & 4.40 \\
32 jam $\left(\mathrm{L}_{32}\right)$ & $3,07 \times 10^{8}$ & 15,23 & 0,2990 & 4.40 \\
\hline
\end{tabular}

\section{Total BAL}

Pertumbuhan merupakan sifat dari mikroorganisme yang paling penting dalam fermentasi. Terdapat empat fase utama dalam pertumbuhan bakteri yaitu: fase lag (fase lamban), fase pertumbuhan eksponensial atau fase $\log$ (fase pertumbuhan cepat), fase stasioner (fase statis) dan fase kematian atau fase penurunan populasi. Fasefase tersebut mencerminkan keadaan bakteri dalam kultur pada waktu tertentu. Kurva pertumbuhan 
Lactobacillus sp. F213 selama fermentasi dapat dilihat pada Gambar 1.

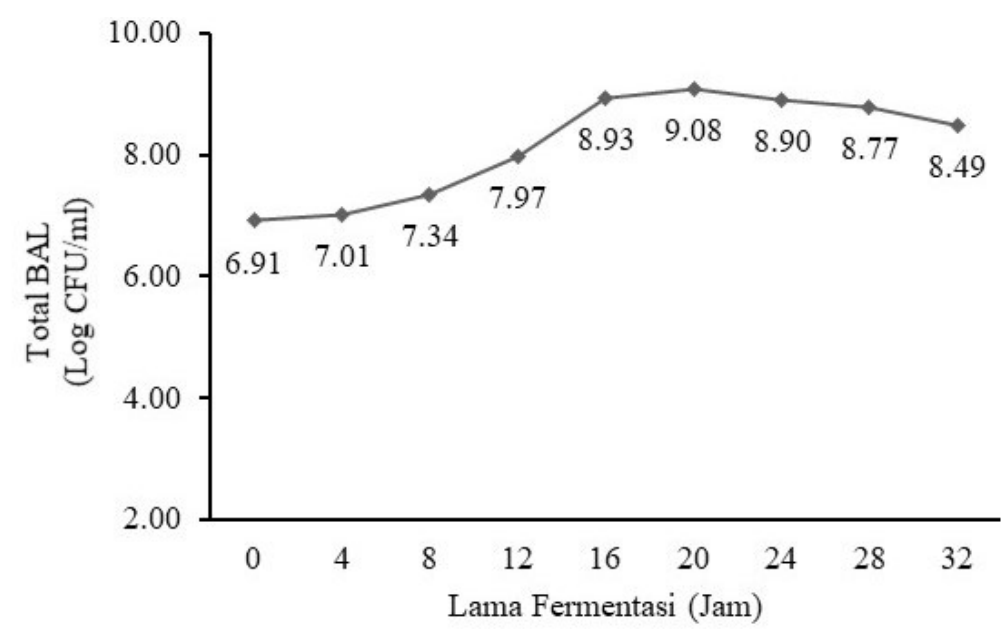

Gambar 1. Grafik pertumbuhan BAL selama fermentasi pada minuman probiotik sari buah terung belanda

Kurva Pertumbuhan pada Gambar 6 menunjukkan bahwa selama fermentasi terjadi peningkatan jumlah sel bakteri dari lama fermentasi 0 jam sampai dengan lama fermentasi 20 jam, total sel bakteri Lactobacillus sp. F213 yang dihasilkan yaitu dari $8,15 \times 10^{6} \mathrm{CFU} / \mathrm{ml}$ sampai dengan $1,2 \times 10^{9} \mathrm{CFU} / \mathrm{ml}$, kemudian pada lama fermentasi 24 jam sampai dengan lama fermentasi 32 jam terjadi penurunan jumlah sel bakteri sampai dengan $3,07 \times 10^{8} \mathrm{CFU} / \mathrm{ml}$.

Pada fermentasi 0 jam hingga 4 jam terjadi peningkatan jumlah sel dari $8,15 \times 10^{6} \mathrm{CFU} / \mathrm{ml}$ menjadi $1,02 \times 10^{7} \mathrm{CFU} / \mathrm{ml}$, diduga selama fermentasi 0 jam hingga 4 jam bakteri Lactobacillus sp. F213 berada dalam fase lag atau fase pertumbuhan awal sehingga pertumbuhan bakteri yang dihasilkan juga belum optimal, fase adaptasi ini terjadi relatif singkat sehingga tidak terlalu terlihat pada kurva. Menurut Yuliana (2008), bakteri asam laktat Isolat T5 dari tempoyak yang ditumbuhkan di MRS Broth juga mengalami fase adaptasi yang singkat yaitu pada fermentasi 0 jam hingga 3 jam, begitu juga dengan pertumbuhan bakteri asam laktat yang diisolasi dari ikan peda kembung, dimana fase adaptasi isolate I5 juga mengalami fase adaptasi pada fermentasi 0 jam hingga 3 jam (Sharah et al., 2015). Fase lag adalah fase dimana mikroba yang diinokulasi akan melakukan adaptasi dengan kondisi lingkungan sekitarnya yang baru. Lamanya fase ini dipengaruhi oleh beberapa faktor seperti media dan lingkungan pertumbuhan serta jumlah inokulum awal. Jika media dan lingkungan pertumbuhan awal sama seperti media dan lingkungan sebelumnya, akan memungkinkan fase adaptasi berjalan lebih cepat. Menurut Marniza dan Rizal (2004), jumlah inokulum juga berpengaruh terhadap lamanya fase adaptasi, dimana semakin tinggi jumlah awal sel maka fase adaptasi akan berlangsung lebih singkat.

Pada fermentasi 8-12 jam terjadi peningkatan jumlah sel sampai dengan $9,36 \times 10^{7}$ $\mathrm{CFU} / \mathrm{ml}$, diduga pada lama fermentasi 8-12 jam, sel bakteri Lactobacillus sp. F213 berada dalam 
fase logaritmik atau fase log atau bisa juga disebut fase pertumbuhan eksponensial. Menurut Ngatirah (2000) bakteri asam laktat seperti Lactobacillus bulgaricus yang ditumbuhkan di MRS Broth mengalami peningkatan jumlah bakteri sampai dengan fermentasi 16 jam, sedangkan Hidayati (2010) menyatakan bahwa Lactobacillus bulgaricus dan S. thermopilus yang ditumbuhkan pada susu kedelai mengalami peningkatan hingga fermentasi 12 jam, sebelum memasuki fase stasioner.Pada fase ini sel bakteri asam laktat akan membelah dengan cepat dan konstan mengikuti kurva logaritmik sehingga pada fase ini bakteri asam laktat biasanya memerlukan energi lebih banyak dibandingkan fase yang lainnya.

Pada fermentasi 16 jam dan 20 jam jumlah sel bakteri Lactobacillus sp. F213 yang dihasilkan secara sampai dengan $1,2 \times 10^{9} \mathrm{CFU} / \mathrm{ml}$, diduga pada pada lama fermentasi 16 jam dan 20 jam bakteri Lactobacillus sp. F213 berada pada fase stasioner atau fase pertumbuhan tetap, dimana pada fase ini bakteri Lactobacillus sp. F213 masih menjalani pertumbuhan, namun tidak optimal. Menurut Hidayati (2010) Lactobacillus planarum yang ditumbuhkan dalam susu kedelai mengalami fase awal stasioner pada fermentasi 16 jam, selain itu bakteri Lactobacillus bulgaricus yang ditumbuhkan dalam MRS Broth juga mengalami fase stasioner pada fermentasi 16 - 18 jam (Ngatirah, 2000). Menurut Judoamidjojo et al., (1990), fase stasioner akan terjadi bila semua sel berhenti membelah diri atau bila sel hidup dan sel mati mencapai keseimbangan. Pada fase ini jumlah populasi sel yang tumbuh hampir sama dengan sel yang mati.
Pada fermentasi 24 jam sampai dengan 32 jam terjadi penurunan jumlah sel bakteri

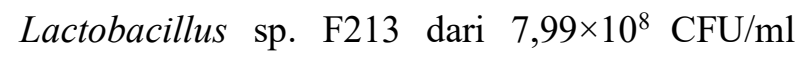
sampai dengan $3,07 \times 10^{8} \mathrm{CFU} / \mathrm{ml}$. Hidayati (2010) menyatakan bahwa bakteri asam laktat Lactobacillus acidophilus yang ditumbuhkan dalam susu kedelai mengalami penurunan populasi pada fermentasi 24 jam. Menurunnya jumlah sel bakteri ini menunjukkan bahwa sel telah memasuki fase menuju kematian. Pada fase ini sel yang mati lebih banyak dibandingkan dengan sel yang tumbuh, hal ini diduga karena nutrisi sudah sangat berkurang dan kondisi lingkungan yang kurang mendukung bagi sel bakteri untuk bertahan hidup akibat dari hasil-hasil metabolisme mikroba itu sendiri.

\section{Total Gula}

Grafik total gula minuman probiotik sari buah terung belanda selama fermentasi dapat dilihat pada Gambar 5. Nilai total gula minuman probiotik sari buah terung belanda berkisar antara $15,23 \%-20,38 \%$.

Berdasarkan hasil analisis total gula pada produk sebelum ditambahkan gula, menunjukkan bahwa total gula yang terdapat pada produk adalah $11,01 \%$, sehingga pada setiap produk yang sudah ditambahkan gula sebanyak $9 \%$ memiliki total gula sebesar 20,38\%. Gambar 5 menunjukkan bahwa selama proses fermentasi terjadi penurunan jumlah total gula, dimana semakin lama fermentasi jumlah gula yang terdapat pada minuman probiotik sari buah terung belanda semakin sedikit. Penurunan total gula pada minuman probiotik sari buah terung belanda sudah sesuai dengan kurva pertumbuhan 
dari Lactobacillus sp. F213, dimana semakin lama fermentasi, jumlah bakteri Lactobacillus sp. F213 yang dihasilkan untuk memecah gula menjadi energi juga semakin banyak, sehingga gula yang terdapat pada minuman sari buah terung belanda juga semakin sedikit. Hal ini sudah sejalan dengan penelitian Retnowati dan Kusnandi (2014), yang menyatakan bahwa semakin banyak sel bakteri asam laktat yang terbentuk maka penggunaan glukosa untuk metabolisme sel juga semakin banyak, sehingga menyebabkan adanya penurunan total gula.

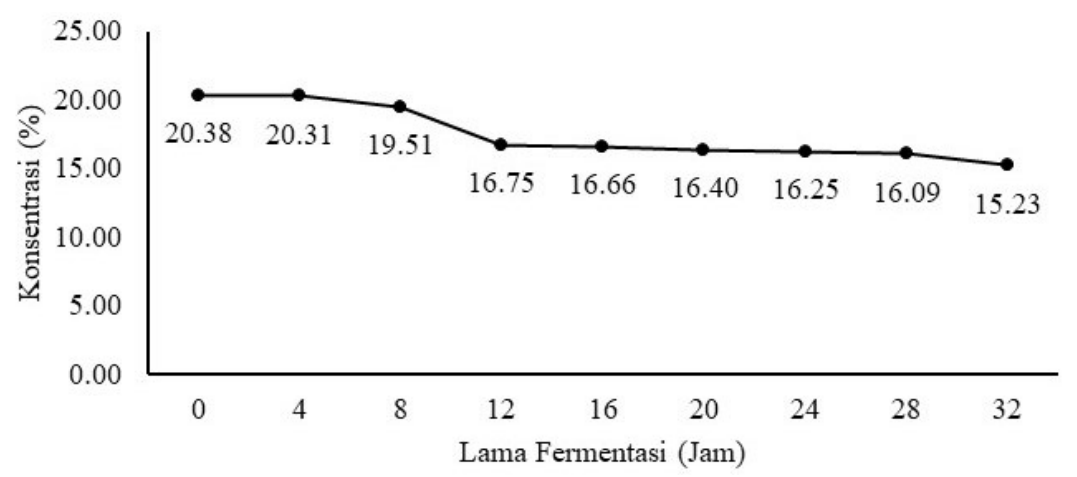

Gambar 5. Grafik perubahan total gula dari minuman probiotik sari buah terung belanda selama fermentasi

Pada lama fermentasi 0-4 jam, penggunaan gula oleh bakteri Lactobacillus sp. F213 yaitu sebanyak $0,07 \%$, hal ini disebabkan karena pada fermentasi 0-4 jam, bakteri Lactobacillus sp. F213 masih berada pada fase adaptasi sehingga tidak menghasilkan jumlah sel yang cukup banyak untuk memecah gula yang terdapat dalam minuman probiotik sari buah terung belanda.

Pada lama fermentasi $8-12$ jam terjadi penurunan total gula sebanyak $2,76 \%$ dimana nilai total gula dari $19,51 \%$ menjadi $16,75 \%$, hal ini dapat terjadi karena pada lama fermentasi 8-12 jam bakteri Lactobacillus sp. F213 sedang berada dalam fase $\log$ atau fase pertumbuhan eksponensial, dimana pada fase ini bakteri Lactobacillus sp. F213 membutuhkan energi lebih banyak dibandingkan fase yang lainnya, sehingga memungkinkan adanya penggunaan gula yang cukup tinggi dan menyebabkan terjadinya penurunan total gula dalam sari buah.

Pada lama fermentasi 16-20 jam terjadi penurunan total gula sebanyak $0,26 \%$ dan dan pada lama fermentasi 24-32 jam jam terjadi penurunan sebanyak $1.02 \%$. Hal ini disebabkan karena pada lama fermentasi 16-24 jam bakteri Lactobacillus sp. F213 sudah memasuki fase statisoner dan pada lama fermentasi 28-32 jam bakteri Lactobacillus sp. F213 sudah memasuki fase menuju kematian, dimana pada kedua fase ini jumlah sel bakteri yang tumbuh sama dengan sel bakteri yang mati bahkan cenderung lebih sedikit. Jumlah sel bakteri yang semakin sedikit ini menyebabkan aktivitas pemecahan gula oleh bakteri tidak berlangsung secara optimal.

\section{Total Asam}

Grafik perubahan total asam minuman probiotik sari buah terung belanda selama 
fermentasi dapat dilihat pada Gambar 6. Nilai total asam minuman probiotik sari buah terung belanda berkisar antara $0,42 \%-0,30 \%$.

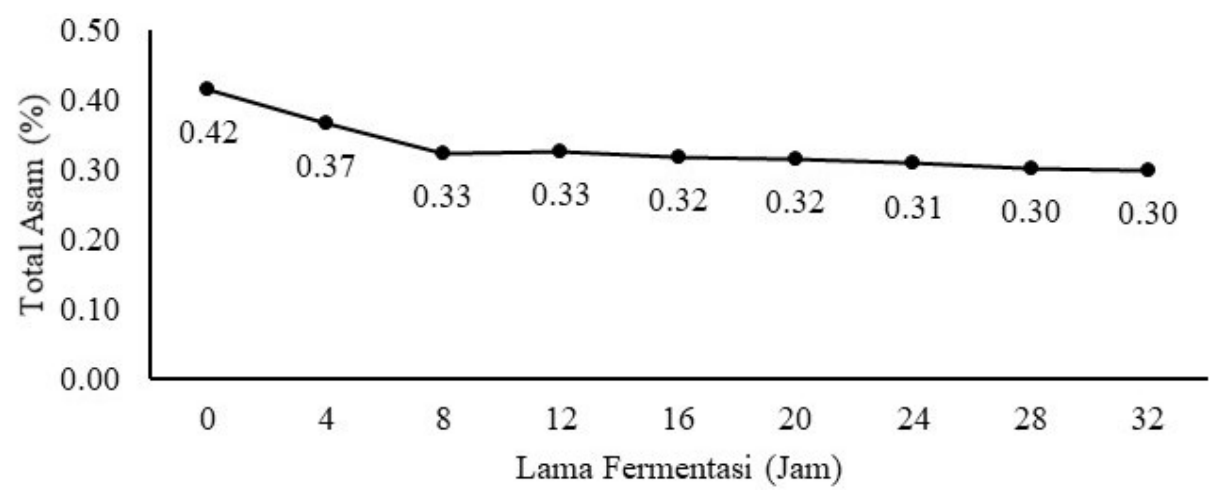

Gambar 6. Grafik perubahan total asam dari minuman probiotik sari buah terung belanda selama fermentasi

Gambar 6 menunjukkan bahwa selama proses fermentasi terjadi penurunan jumlah total asam, dimana total asam menurun dari $0,42 \%$ menjadi $0,30 \%$. Penurunan total asam diduga akibat dari bakteri Lactobacillus sp. F213 yang mengalami stress. Beberapa faktor yang dapat mengaktifkan respon stress pada bakteri yaitu salinitas, suhu, osmolalitas dan variasi nilai $\mathrm{pH}$. Nilai pH pada minuman sari buah terung belanda yang belum terfermentasi dengan penambahan gula 9\%, yaitu sebesar 3,96. Pelczar (1988) mengatakan bahwa bakteri Lactobacillus spp, merupakan jenis mikroba mesofilik karena hidup pada $\mathrm{pH}$ berkisar 4,5-6,5 dengan $\mathrm{pH}$ optimum yaitu 6 Menurut Krulwich dan Sachs (2011) rendahnya nilai $\mathrm{pH}$ pada lingkungan dapat mempengaruhi nilai $\mathrm{pH}$ intraseluler dari sel bakteri sehingga menghasilkan stress pada bakteri, sehingga bakteri harus melakukan beberapa aktivitas sebagai bentuk adaptasi agar mampu bertahan hidup selama melewati fase stress, aktivitas ini menyebabkan adanya perubahan stabilitas susunan protein pada sitosol yang dapat mempenngaruhi aktivitas enzim.

Beberapa hal yang dapat dilakukan oleh bakteri untuk bertahan hidup dengan lingkungan $\mathrm{pH}$ yang rendah atau biasa disebut $\mathrm{pH}$ homeostasis yaitu seperti merubah aktivitas enzim pada jalur metabolisme tertentu, memodifikasi komposisi lipid dari membran sel, menggunakan proton oleh sistem dekarboksilase yang bergantung pada asam amino dan netralisasi dengan cara menghasilkan senyawa yang bersifat alkali (Krulwich dan Sachs 2011; Padan et al 2005). Ramos et al., (2014) mengatakan bahwa Lactobacillus plantarum dan Lactobacillus brevis mengalami $\mathrm{pH}$ homeostasis ketika ditumbuhkan di dalam cairan lambung (gastric juice) yang memiliki nilai $\mathrm{pH}$ sebesar 3,5. Carme et al., (2008) pada penelitiannya tentang Lactobacillus plantarum yang ditumbuhkan pada jus timun dengan media MRS Broth sebagai kontrol menunjukkan bahwa terdapat respon stress yang kemudian menyebabkan terjadinya perubahan stabilitas pada susunan protein sehingga mempengaruhi aktivitas enzim selama 
metabolisme, perubahan aktivitas enzim ini menyebabkan jumlah asam laktat dan asam asetat yang dihasilkan pada jus timun lebih sedikit dibandingkan dengan jumlah asam laktat dan asam asetat yang dihasilkan pada MRS Broth. Pada penelitian ini penurunan total asam diduga terjadi karena Lactobacillus sp. F213 mengalami stress akibat dari rendahnya nilai $\mathrm{pH}$ pada minuman sari buah terung belanda, respon stress ini menyebabkan adanya perubahan pada aktivitas enzim selama metabolisme sehingga menurunkan kemampuan bakteri Lactobacillus sp. F213 untuk menghasilkan asam asetat dan asam laktat. Selain itu Lactobacillus sp F213 merupakan bakteri yang bersifat homofermentatif, dimana selama fermentasi bakteri tidak hanya menghasilkan asam laktat melainkan juga menghasilkan senyawa senyawa lainnya seperti $\mathrm{CO} 2$, etanol dan asam asetat, sehingga produksi dari asam laktat yang dihasilkan juga tidak optimal seperti bakteri homofermentatif.

pH

Grafik perubahan nilai $\mathrm{pH}$ minuman probiotik sari buah terung belanda selama fermentasi dapat dilihat pada Gambar 7. Nilai $\mathrm{pH}$ minuman probiotik sari buah terung belanda berkisar antara 4,18-4,41.

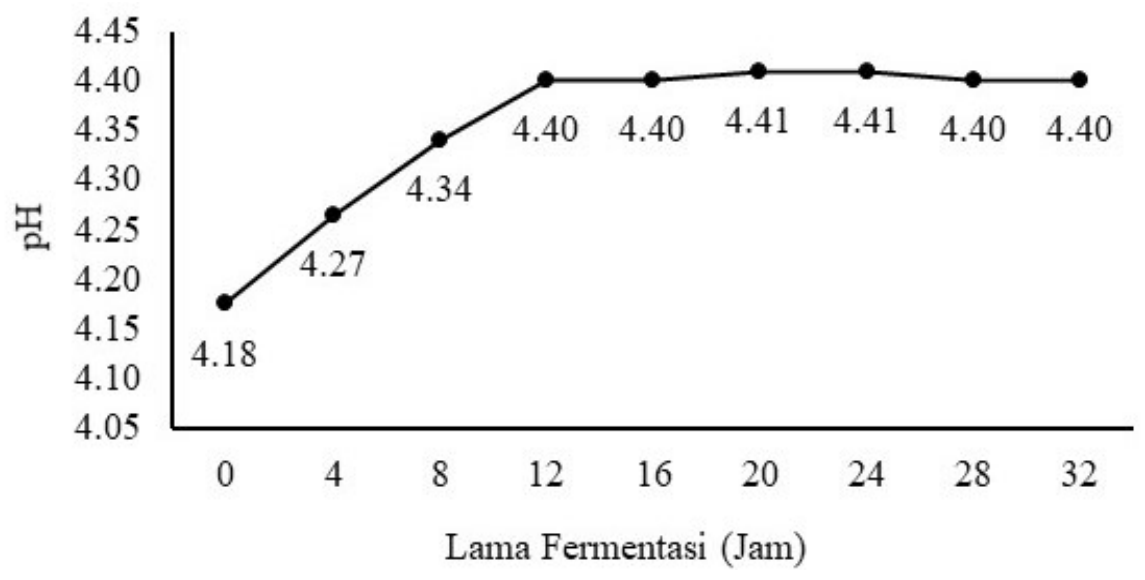

Gambar 7. Grafik perubahan nilai $\mathrm{pH}$ dari minuman probiotik sari buah terung belanda selama fermentasi

Gambar 7 menunjukkan bahwa selama proses fermentasi berlangsung terjadi peningkatan nilai $\mathrm{pH}$ pada lama fermentasi 0 jam sampai dengan lama fermentasi 24 jam, kemudian $\mathrm{pH}$ menurun pada fermentasi 28 jam sampai dengan 32 jam. Kenaikan $\mathrm{pH}$ pada minuman sari buah terung belanda sejalan dengan adanya penurunan total asam. Menurut Alvarado et al., (2006) nilai pH berhubungan erat dengan total asam yang dihasilkan, jika total asam yang dihasilkan meningkat maka nilai $\mathrm{pH}$ yang dihasilkan akan menurun begitu pula sebaliknya. Kenaikan nilai $\mathrm{pH}$ diduga terjadi karena bakteri Lactobacillus sp. F213 menghasilkan senyawa - senyawa yang bersifat alkali, sebagai bentuk adaptasi untuk bertahan hidup pada media yang memiliki nilai $\mathrm{pH}$ rendah. Nilai $\mathrm{pH}$ pada minuman sari buah terung belanda yang belum terfermentasi dengan penambahan gula $9 \%$, yaitu sebesar 3,96. Pelczar (1988) mengatakan bahwa bakteri Lactobacillus 
spp, merupakan jenis mikroba mesofilik karena hidup pada $\mathrm{pH}$ berkisar 4,5-6,5 dengan nilai $\mathrm{pH}$ optimum yaitu 6. Untuk beradaptasi dengan lingkungan $\mathrm{pH}$ yang rendah dan menjaga $\mathrm{pH}$ intraseluler agar tidak mengalami lisis atau biasa disebut $\mathrm{pH}$ homeostasis, bakteri dapat melakukan beberapa hal seperti merubah aktivitas enzim pada jalur metabolisme tertentu, memodifikasi komposisi lipid dari membran sel, menggunakan proton oleh sistem dekarboksilase yang bergantung pada asam amino dan netralisasi dengan cara menghasilkan senyawa yang bersifat alkali (Krulwich dan Sachs 2011; Padan et al 2005). Ramos et al., (2014) mengatakan bahwa Lactobacillus plantarum dan Lactobacillus brevis mengalami $\mathrm{pH}$ homeostasis ketika ditumbuhkan di dalam cairan lambung (gastric juice) yang memiliki nilai $\mathrm{pH}$ sebesar 3,5. Pada penelitian ini, kenaikan $\mathrm{pH}$ diduga terjadi karena bakteri Lactobacillus sp. F213 melakukan beberapa usaha adaptasi untuk bertahan hidup pada sari buah terung belanda seperti menghasilkan senyawa yang bersifat alkali yang menyebabkan lingkungan menjadi bersifat basa, sehingga nilai $\mathrm{pH}$ yang dihasilkan meningkat. Selain itu Lactobacillus sp. F213 merupakan bakteri yang bersifat heterofermentatif dimana selama fermentasi bakteri Lactobacillus sp. F213 tidak hanya menghasilkan asam laktat, melainkan juga menghasilkan senyawa lainnya seperti $\mathrm{CO}_{2}$, asam asetat dan etanol, dimana senyawa asam asetat dan etanol memiliki gugus $\mathrm{OH}^{-}$yang dapat mempengaruhi nilai $\mathrm{pH}$ yang dihasilkan. Peningkatan nilai $\mathrm{pH}$ terjadi karena selama fermentasi 0-12 jam, bakteri asam laktat sedang berada dalam fase lag dan fase pertumbuhan eksponensial, dimana pada fase ini pemecahan gula menjadi senyawa etanol dan $\mathrm{CO}_{2}$ berlangsung secara optimal, karena sel bakteri pada pertumbuhan ini mengalami pertumbuhan dengan cepat. Menurut Wang et al., (2006), proses produksi etanol oleh mikroorganisme anaerob akan berlangsung lebih optimal pada $\mathrm{pH} 4-5$, sehingga produksi etanol yang optimal ini akan menyebabkan gugus $\mathrm{OH}^{-}$pada minuman semakin banyak, sehingga dapat menyebabkan terjadinya peningkatan nilai $\mathrm{pH}$. Selain itu lingkungan yang bersifat asam juga menyebabkan stress pada bakteri Lactobacillus sp. F213 sehingga kemampuan bakteri Lactobacillus sp. F213 untuk menghasilkan asam laktat dan asam asetat semakin menurun,

\section{KESIMPULAN DAN SARAN}

\section{Kesimpulan}

Berdasarkan hasil penelitian yang telah dilakukan dapat diambil kesimpulan sebagai berikut :

1. Pola pertumbuhan Lactobacillus sp. F213 pada minuman probiotik sari buah terung belanda yaitu pada lama fermentasi 0-4 jam, bakteri Lactobacillus sp. F213 berada pada fase lag atau fase adaptasi, kemudian pada lama fermentasi 8-12 jam bakteri Lactobacillus sp. F213 berada dalam fase $\log$ atau fase eksponensial. Pada lama fermentasi 16 jam dan 20 jam bakteri Lactobacillus sp. F213 sudah berada dalam fase stasioner dan pada lama fermentasi 24-32 jam bakteri Lactobacillus sp. F213 sudah berada dalam fase menuju kematian. 
2. Pertumbuhan optimum dari bakteri Lactobacillus sp. F213 pada sari buah terung belanda terjadi pada lama fermentasi 20 jam dengan jumlah total BAL yang dihasilkan mencapai $1,2 \times 10^{9} \mathrm{CFU} / \mathrm{ml}$.

\section{Saran}

Perlu dilakukan penelitian lebih lanjut untuk mengetahui kurva pertumbuhan dari Lactobacillus sp. F213 pada sari buah terung belanda berdasarkan analisa kadar biomassa.

\section{DAFTAR PUSTAKA}

Alvarado, S., B.E.G Almendarez., S.E. Martin dan C. Regalado. (2006). Food-associated Lactic Acid Bacteria with Antimicrobial Potential from Traditional Mexican Foods. Microbiologia. 48(3-4): 206-268.

Andarwulan, N., F. Kusnandar, dan D. Herawati. (2011). Analisis Pangan. Dian Rakyat. Jakarta.

Bouton, P.E. dan P.V. Harris. (1972). All About Yoghurt. Prentice Hall, Inc., Englewood Cliffs, New Jersey.

BPOM RI. 2005. Peraturan Kepala Badan Pengawasan Obat dan Makanan Republik Indonesia Tentang Ketentuan Pokok Pengawasan Pangan Fungsional. BPOM. Jakarta.

Carme P.F., K.M. Koistine., T.L. Tolonen, dan S.J. Lehesranta. (2008). Comparative Study of Sugar Fermentation and Protein Expression Patterns of Two Lactobacillus plantarum Strains Grown in Three Different Media. Applied and Environmental Microbiology. 74(17): 5349-5358.

Ding, W.K. dan N.P. Shah. (2008). Survival of Free and Microencapsulated Probiotic Bacteria in Orange and Apple Juices. International Food Journal 15 (2): 219-232.

Djufry, F., J. Limbongan, N. Lade, dan B. Saranga. (2016). Karakterisasi tanaman tamarillo di Sulawesi Selatan. Bul. Plasama Nutfah. 22(2): 127-136.

FAO/WHO. (2001). Joint FAO/WHO Expert Consultation on Evaluation of Health and
Nutritional Properties of Probiotics in Food Including Powder Milk with Live Lactic Acid Bacteria. Amerian Cordoba Park Hotel, Cordoba, Argentina. http://www.fao.org/documents/pub dett.asp ?lang=end\&pub id=61756

Fardiaz, S. (1993). Mikrobiologi Pangan I. Gramedia Pustaka Utama. Jakarta.

Farnworth, R.E. (2008). Handbook of Fermented Functional Foods. Second Ed. CRC Press. USA.

Febricia, G.P., K.A. Nocianitri, dan I.D.P.K. Pratiwi. (2020). Pengaruh Lama Fermentasi terhadap Karakteristik Minuman Probiotik Sari Buah Terung Belanda (Solanum betaceum Cav) dengan Isolat Lactobacillus sp. F213. Jurnal Itepa. 9(2): 170-180.

Hidayati, D. (2010). Pola Pertumbuhan Bakteri Asam Laktat Selama Fermentasi Susu Kedelai. Jurnal Teknologi Hasil Pertanian 3(2): 72-76.

Judoamidjojo, M., A.A. Darwis, dan E.G. Sa'id. (1990). Tekonologi Fermentasi. Rajawali Press. Jakarta.

Krulwich, T.A., G. Sachs. 2011. Molecular aspects of bacterial $\mathrm{pH}$ sensing and homeostasis. Nat Rev Microbiol. 9: 330-343.

Marniza dan S. Rizal. (2004). Tekonologi Fermentasi. TPSDP Universitas Lampung. Bandar Lampung.

Ngatirah. (2000). Seleksi Bakteri Asam Laktat Sebagai Agensia Probiotik yang Berpotensi Menurunkan Kolesterol. Universitas Gadjah Mada. Yogyakarta.

Padan, E., E. Bibi., M. Ito. (2005). Alkaline pH homeostasis in bacteria: New Insights. Biochim Biopys Acta Biomembr. 17: 67-88.

Pelczar, C. (1988). Dasar - dasar Mikrobiologi Jilid 2. UI Press. Jakarta.

Prado, F.C., J.L.Parada., A.Phandey., dan C.R.Soccol. (2007). Trends in Non-dairy Probiotic Beverages. Food Research International (41): 111-123.

Ramos, C.L., L. Thorsen., M. Ryssel., D.S. Nielsen., H., Siegumfeldt., R.F. Schwan dan L. Jespersen. (2014). Effect of the gastrointestinal environment on $\mathrm{pH}$ homeostasis of Lactobacillus plantarum and Lactobacillus brevis cells as measured by real-time fluorescence ratio-imaging microscopy. Research in Microbiology. 165: 215-225. 
Ramos, C.L., L. Thorsen., M. Ryssel., D.S. Nielsen., H., Siegumfeldt., R.F. Schwan dan L. Jespersen. (2014). Effect of the gastrointestinal environment on $\mathrm{pH}$ homeostasis of Lactobacillus plantarum and Lactobacillus brevis cells as measured by real-time fluorescence ratio-imaging microscopy. Research in Microbiology. 165: 215-225.

Reid, G., E. Di Stefano, J. White, S. Seney, dan M. Sumarah. (2017). A Novel Millet Based Probiotic Fermented Food for The Developing Word. Journal of Nutrients. (9): 529

Retnowati, P.A., dan J. Kusnandi. (2014). Pembuatan Minuman Probiotik Sari Buah Kurma (Phoenix dactylifera) dengan Isolat Lactobacillus casei dan Lactobacillus plantarum. Jurnal Pangan dan Agroindustri. 2(2): 70-81

Rini, A.P., K.A. Nocianitri, dan N.M.I. Hapsari. (2019). Viabilitas Lactobacillus sp. F213 pada Berbagai Minuman Sari Buah Probiotik Selama Penyimpanan. Jurnal Ilmu dan teknologi Pangan. 8(4): 408-418.

Ritter, P., C. Kohler, dan U. von Ah. (2009). Evaluation of the passage of Lactobacillus gasseri $\mathrm{K} 7$ and bifidobacteria from the stomach to intestines using a sngle reactor model. BMC Microbiology. (9): 87.

Ruck. (1963). Hot-Loop Test for the Determination of Carbon Dioxide Production from Glucose by lactid Acid Bakteria. Appl. Environ Microbial 6(36): 990- 991.

Sharah, A., R. Karnila., dan Desmelati. (2015). Pembuatan Kurva Pertumbuhan Bakteri Asam Laktat yang Diisolasi dari Ikan Peda Kembung (Rastrelliger $s p$.). Jurnal Online
Mahasiswa Bidang Perikanan dan Kelautan 2(2): 1-8.

Sujaya, I N., K.A. Nocianitri, Y. Ramona, D.M. Sukrama, M.A. Wirawan, dan N.N.D. Fatmawati. (2015). Lama kolonisasi Lactobacillus sp F213 pada saluran pencernaan dalam upaya pengembangan probiotik untuk menurunkan kolesterol. Penelitian Strategis Nasional, (Laporan).

Suryani, Y., A. B. Oktavia., dan S. Umniyati. (2010). Isolasi dan Karakterisasi Bakteri Asam Laktat dari Limbah Kotoran Ayam sebagai Agensi Probiotik dan Enzim Kolesterol Reduktase. Biologi dan Pengembangan Profesi Pendidik Biologi. Biota. 12 (3): 177-185.

Wang, L., Q. Zhou., dan G. Zheng. (2006). Comprehensive Analysis of The Factors for Propionic Acid Accumulation in Acidogenic Phase of Anaerobic Process. Environmental Technology. 27(3): 269-276.

Wenge, F., dan A.F. Methews. (1999). Lacticd acid production from lactose by Lactobacillus plantarum kinetic models and effect of $\mathrm{pH}$, substrate and oxygen. Biochemical Engineering Journal (3): 163-170.

Yoon, K.Y., E.E. Woodams., dan Y.D. Hong. (2004). Probiotication of Tomato Juice by Lactic Acid Bacteria. The Journal of Microbiolgy 43(4): 315-318.

Yuliana, N. (2008). Kinetika Pertumbuhan Bakteri Asam Laktat Isolat T5 yang berasal dari Tempoyak. Jurnal Teknologi Industri dan Hasil Pertanian 13(2): 108-116.

Zubaidah, E., Y. Liasari., dan E. Saparianti. (2008). Produksi Eksopolisakarida oleh Lactobacillus plantarum B2 pada Produk Probiotik Berbasis Buah Murbei. Jurnal Teknologi Pertanian 1(9): 59-68. 